\title{
Comparative Metabolomics Profiling of Polyphenols, Nutrients and Antioxidant Activities of Two Red Onion (Allium cepa L.) Cultivars
}

\author{
Rita Metrani ${ }^{1,2}$, Jashbir Singh 1,2 ${ }^{1 D}$, Pratibha Acharya ${ }^{1,2} \mathbb{D}$, \\ Guddadarangavvanahally K. Jayaprakasha ${ }^{1,2, *(D)}$ and Bhimanagouda S. Patil 1,2,*(D) \\ 1 Vegetable \& Fruit Improvement Center, Department of Horticultural Sciences, Texas A\&M University, \\ 1500 Research Parkway, Suite A120, College Station, TX 77845-2119, USA; ritametrani@tamu.edu (R.M.); \\ singh2014@tamu.edu (J.S.); pratibha@tamu.edu (P.A.) \\ 2 National Center of Excellence for Melon at the Vegetable and Fruit Improvement Center of Texas A\&M \\ University, College Station, TX 77845, USA \\ * Correspondence: gkjp@tamu.edu (G.K.J.); b-patil@tamu.edu (B.S.P.)
}

Received: 1 August 2020; Accepted: 19 August 2020; Published: 21 August 2020

\begin{abstract}
Onion is among the most widely cultivated and consumed economic crops. Onions are an excellent dietary source of polyphenols and nutrients. However, onions phytonutrient compositions vary with cultivars and growing locations. Therefore, the present study involved the evaluation of polyphenol, nutritional composition (proteins, nitrogen, and minerals), sugars, pyruvate, antioxidant, and $\alpha$-amylase inhibition activities of red onion cultivars, sweet Italian, and honeysuckle grown in California and Texas, respectively. The total flavonoid for honeysuckle and sweet Italian was 449 and $345 \mu \mathrm{g} / \mathrm{g} \mathrm{FW}$, respectively. The total anthocyanin for honeysuckle onion was $103 \mu \mathrm{g} / \mathrm{g}$ FW, while for sweet Italian onion was $86 \mu \mathrm{g} / \mathrm{g}$ FW. Cyanidin-3-(6"-malonoylglucoside) and cyanidin-3-(6"-malonoyl-laminaribioside) were the major components in both the cultivars. The pungency of red onions in honeysuckle ranged between 4.9 and $7.9 \mu \mathrm{moL} / \mathrm{mL}$, whereas in sweet Italian onion ranged from 8.3 to $10 \mu \mathrm{moL} / \mathrm{mL}$. The principal component analysis was applied to determine the most important variables that separate the cultivars of red onion. Overall results indicated that total flavonoids, total phenolic content, total anthocyanins, protein, and calories for honeysuckle onions were higher than the sweet Italian onions. These results could provide information about high quality and adding value to functional food due to the phytochemicals and nutritional composition of red onions.
\end{abstract}

Keywords: Allium cepa L.; honeysuckle; sweet Italian; flavonoids; anthocyanins

\section{Introduction}

Onions are among the most widely grown, consumed, and important economic crops [1]. They are consumed alone or in prepared foods for their unique pungent flavor and sugar content [2]. According to the U.S Statista, the consumption of fresh onions accounted for 20.4 pounds per capita in 2019 [3]. Onions are excellent sources of polyphenols, contribute significantly to the human diet, and have been used in the prevention of infections, cancer, cardiovascular disease, and hyperlipidemia $[4,5]$.

Polyphenols are receiving increasing interest from consumers and food manufacturers due to antioxidant and anti-inflammatory benefits that help prevent illnesses and diseases. Polyphenols are natural substances in plants and include compounds such as phenolic acids and flavonoids [6]. Flavonoids are further categorized into six different subclasses: flavonols, flavones, isoflavones, flavanones, anthocyanins, and flavanols, forming the largest group with antioxidant effects [7]. Health benefits of phenolics attract the researcher and breeders to identify and develop new cultivars 
with enhanced functional properties [8,9]. Selective breeding of red onion with the phenolic-rich content and high antioxidant activity can provide various health benefits [10].

Onions are a rich source of flavonoids, mainly quercetin mono- and diglucosides, kaempferol, isorhamnetin, and myricetin [11]. Flavonoids possess numerous health beneficial properties such as anticarcinogenic, anticholesterol, antidepressant, antifungal, antidiabetic, antioxidant, etc. [12]. Nishimura et al. reported that the daily intake of onion rich in quercetin might improve liver function and have anti-obesity effects [13]. Due to the structural functionalities, quercetin has maximum radical scavenging activity and acts as a potent antioxidant, representing the main antioxidative flavonol in the human diet [14]. Antioxidants have the capacity to prevent and slow the oxidation of molecules. These oxidation reactions produce free radicals, thus causing damage to cells [15]. Flavonoids in onion have strong antioxidant activity due to the presence of hydroxyl groups, which may help to prevent coronary heart disease and tumors [16]. Flavonoid contents vary in the different layers (outer paper layer, first flesh layer, second flesh layer and inner flesh layer) of onion, and results showed that significantly higher flavonoid content was observed in the first layer as compared to others layers [17]. A short-day red onion (TX 90977) was reported to contain $101.2 \mu \mathrm{g} / \mathrm{g}$ of total quercetin [18]. The southern Italian red onion had two major flavonoids such as quercetin- $4^{\prime}$-glucoside (208 to $230 \mu \mathrm{g} / \mathrm{g}$ ) and quercetin-3,4'-diglucoside (254 to $274 \mu \mathrm{g} / \mathrm{g} \mathrm{FW)} \mathrm{[19].}$

The red variety of onions is mainly due to the presence of pigment anthocyanins. Anthocyanins are hydrophilic pigments which belong to the subclass of flavonoids. They are glycosides of anthocyanidin and responsible for the red or blue coloration in fruits, flowers, and other plant parts [20,21]. Anthocyanins are potent free radical scavengers and have demonstrated protection against oxidative DNA cleavage, enzyme inhibition, oxidative degradation of lipids, and membrane strengthening [14]. They have anticancer, anti-inflammatory, and antidiabetic activities. They also improve cardiovascular health and prevention against Alzheimer's and Parkinson's diseases [22-24]. In onion germplasm, cyanidin derivatives are the major while others such as pelargonidin and delphinidin derivatives are the minor anthocyanins [25].

Onions are also rich in minerals (potassium and iron), vitamins, and dietary fiber [15]. The effect of onion phenolic phytochemicals on hyperglycemia has been investigated. Previous studies reported that polyphenols such as quercetin, naringenin, catechins, epicatechins, chlorogenic acids, ferulic acids, caffeic acid, and tannic acids had $\alpha$-amylase inhibiting effects [26,27]. The inhibition of $\alpha$-amylase enzyme prevents the breakdown of polysaccharides to monosaccharides resulting in the lowering of the blood sugar level [28]. Therefore, phenolic enriched plants such as onions may possess many therapeutic benefits.

The aim of this research was to quantify the phytonutrients present in two varieties-honeysuckle and sweet Italian onions-which are the most widely consumed red onions in the United States. To our knowledge, there is no study reporting the content of phytonutrient (flavonoids, anthocyanins, total phenolics), antioxidant activity (ABTS, DPPH), $\alpha$-amylase inhibition activity, and pungency levels in these cultivars.

\section{Results and Discussion}

Honeysuckle red onions from J\&D Produce, Inc., Texas and Artisan sweet Italian red onions from Tanimura \& Antle, California, were used for the entire study (Figure 1).

\subsection{Pungency, Total Soluble Solids, and Sugars}

Maceration of onion tissue causes generation of pyruvic acid, ammonia, and sulfur related compounds due to the reaction of the enzyme alliinase with (S)-alk(en)yl cysteine sulfoxide. The sulfur compounds as an unstable and pyruvic acid as a stable compound have been used as an indicator of onion pungency $[29,30]$. The pungency of onion is presented in Figure 2A. The mean pyruvic acid content ranged between 6.3 (honeysuckle) and 9.1 (sweet Italian) $\mu \mathrm{moL} / \mathrm{mL}$. There was a significant variation between the red onions of two cultivars. According to Liguori et al., the level of pungency 
is as follows: low, $0-3 \mu \mathrm{moL} / \mathrm{mL}$; moderate, $3-7 \mu \mathrm{moL} / \mathrm{mL}$; high, $>7 \mu \mathrm{moL} / \mathrm{mL}$ [31]. The Brix of two cultivars was 10.9 (honeysuckle) and 11 (sweet Italian) and did not show any significant difference. The red onions are generally regarded as high in pungency and Brix.

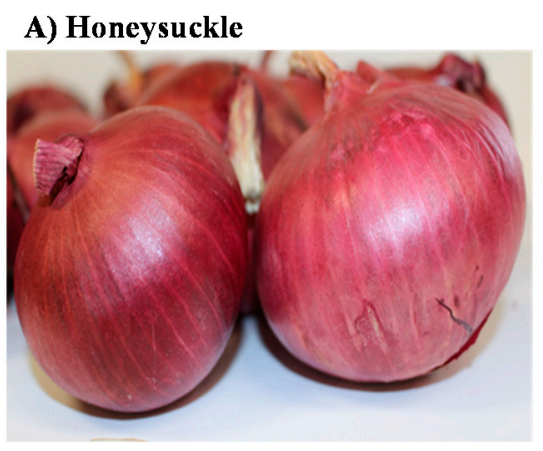

\section{B) Sweet Italian}

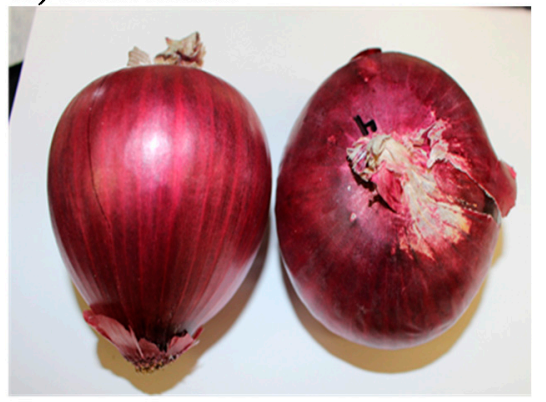

Figure 1. Onion varieties (A) honeysuckle and (B) sweet Italian.

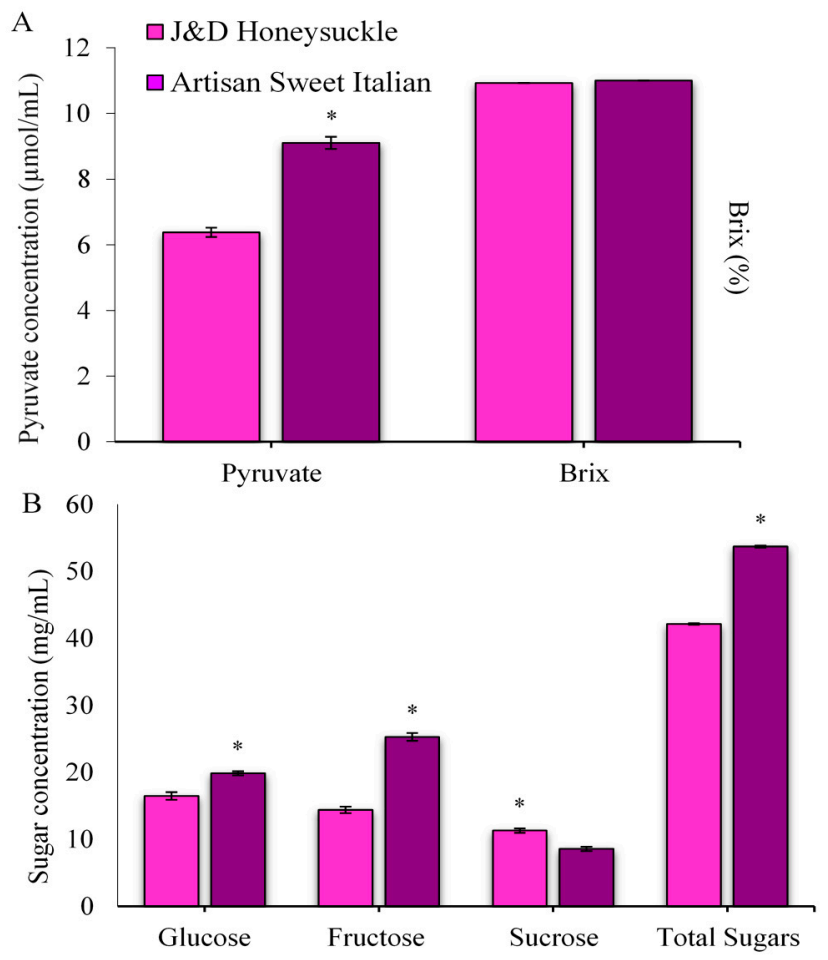

Figure 2. (A) Pyruvate concentration and Brix of red onion juice; (B) sugar concentration of red onion juice. * Above the bars of each cultivar indicate significant differences as determined by a Student's $t$-test at $p<0.05$.

The glucose, fructose, and sucrose were detected in all the onion samples (Figure 2B). The glucose $(19.8 \mathrm{mg} / \mathrm{mL})$ and fructose $(25.2 \mathrm{mg} / \mathrm{mL})$ were high in sweet Italian, whereas the sucrose $(11.29 \mathrm{mg} / \mathrm{mL})$ was high in the honeysuckle variety. The total sugar ranged between 42.13 (honeysuckle) and 53.68 (sweet Italian) $\mathrm{mg} / \mathrm{mL}$.

\subsection{Evaluation of Protein and Minerals}

Onion serves as a good supplement of magnesium, calcium, iron, sodium, phosphorous, boron, and potassium. Although onions constitute a small portion of the whole diet, they play an important role in metabolic processes and normal functioning of the human body. The results obtained for the mineral and protein content analyzed in all the samples and their differentiation, according to 
the cultivars are shown in Table 1. Phosphorous helps to keep bones strong and repair damaged tissues [32]. The highest level of phosphorous was seen in sweet Italian cultivar $(2677.64 \mu \mathrm{g} / \mathrm{g})$ and the lowest in honeysuckle $(2525.63 \mu \mathrm{g} / \mathrm{g})$. Potassium plays an important role in maintaining water balance, regulation of heartbeat, and neurotransmission [33]. The highest level of potassium $(13,550.1 \mu \mathrm{g} / \mathrm{g})$ was observed in sweet Italian and lowest $(12,720.37 \mu \mathrm{g} / \mathrm{g})$ in honeysuckle.

Table 1. The nutritional component of the red onions from two cultivars.

\begin{tabular}{ccc}
\hline Nutritional Component & Honeysuckle & Sweet Italian \\
\hline & \multicolumn{2}{c}{$\mu \mathrm{g} / \mathrm{g}$} \\
Phosphorus & 2525.63 & 2677.64 \\
Potassium & $12,720.67$ & $13,550.1$ \\
Calcium & 3183.54 & 2506.5 \\
Magnesium & 980.43 & 1100.62 \\
Sodium & 1001.34 & 314.13 \\
Zinc & 14.43 & 12.23 \\
Iron & 23.16 & 27.69 \\
Copper & 7.38 & 3.19 \\
Manganese & 6.03 & 9.22 \\
Sulfur & 3421.58 & 3415.67 \\
Boron & 18.34 & 15.34 \\
& & $\%$ \\
Nitrogen & 1.47 & 1.31 \\
Protein & 9.21 & 8.2 \\
\hline
\end{tabular}

Magnesium helps in the carbohydrate metabolism, a cofactor in more than 300 enzymatic reactions, stabilizes protein, and calcium absorption for bones [34]. The average consumption of magnesium for men is $420 \mathrm{mg}$ and women is $320 \mathrm{mg}$. The values for magnesium in sweet Italian and honeysuckle were 1100.62 and $980.43 \mu \mathrm{g} / \mathrm{g}$, respectively. Calcium, sodium, zinc, copper, sulfur, and boron were high in honeysuckle with the values 3183.52, 1001.34, 14.43, 7.38, 3421.58, and $18.34 \mu \mathrm{g} / \mathrm{g}$, respectively. Sodium regulates the body's water content and helps in the absorption of certain nutrients, while iron is essential for the formation of hemoglobin in red blood cells [35]. Zinc acts as a cofactor for enzymes and helps in reproductive development [36], whereas copper is important for infant growth and producing red and white blood cells. Manganese is a constituent of antioxidant enzyme which helps to prevent free radical-mediated damage to cells. Boron helps the body to metabolize vitamins and minerals [37], whereas sulfur helps to build and repair DNA and protect cells against damage [38]. The protein percentage in honeysuckle (9.21) was higher than the sweet Italian (8.2). Minerals play an essential role from building strong bones to transmitting nerve impulses. There were differences between the concentrations of all the mineral elements studied in the two red onion cultivars. It can, therefore, be assumed that the environment, agronomic practices, and genetic information of the seeds determine the changes in the protein and mineral element composition.

\subsection{Antioxidant Activity, Total Phenolic Content, and $\alpha$-Amylase Inhibitory Activity}

The DPPH assay is applicable to hydrophobic compounds, whereas ABTS is applicable to both hydrophilic and hydrophobic compounds which provide a flexibility to be used for samples extracted at different $\mathrm{pH}$ levels. DPPH and ABTS free radicals react with chemicals compounds by single electron and hydrogen atom transfer mechanisms, respectively $[39,40]$. The antioxidant activity was measured using DPPH and ABTS assays (Figure 3A,B). There was no significant difference in DPPH activity in sweet Italian onion and honeysuckle with the value of 262.93 and 259.75, respectively. ABTS radical scavenging activity was high in sweet Italian onions $(193.82 \mu \mathrm{g} / \mathrm{g})$ compared to honeysuckle onions $(173.27 \mu \mathrm{g} / \mathrm{g})$. Sagar et al. [41], Wu et al. [42], and Lu et al. [43] reported 66.79-94.17 $\mu \mathrm{g} \mathrm{GA} / \mathrm{g}, 103.91 \mu \mathrm{g}$ AA/g, and $1301.508 \mu \mathrm{g}$ Trolox/g FW DPPH radical scavenging activity in red onions. 

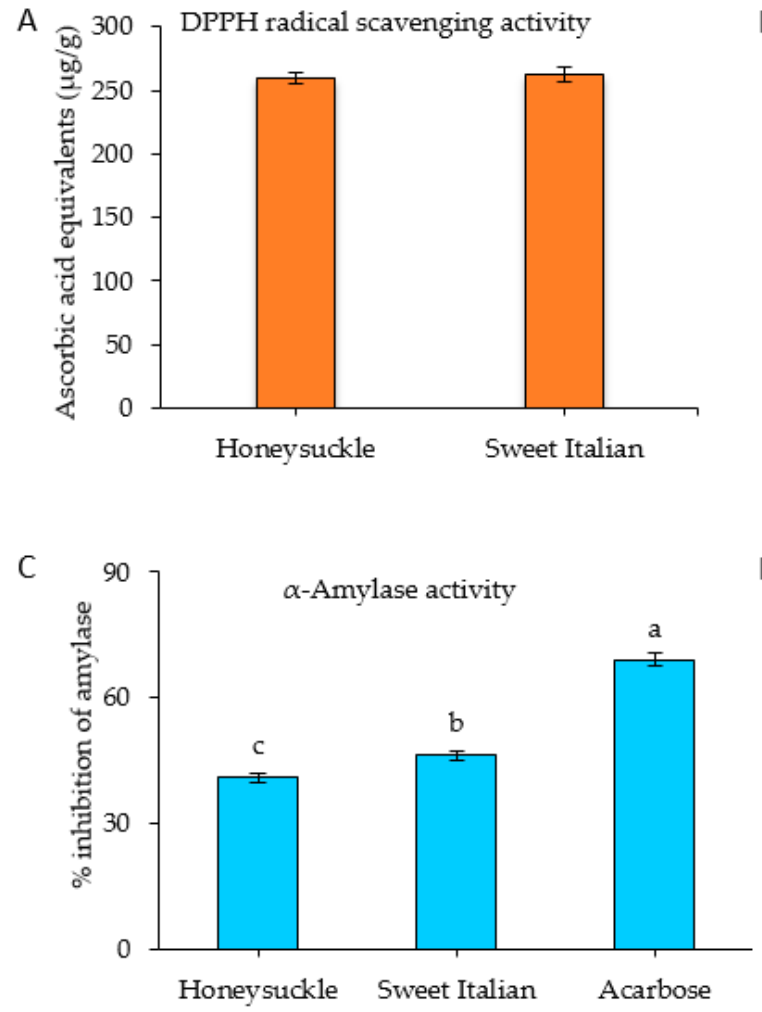
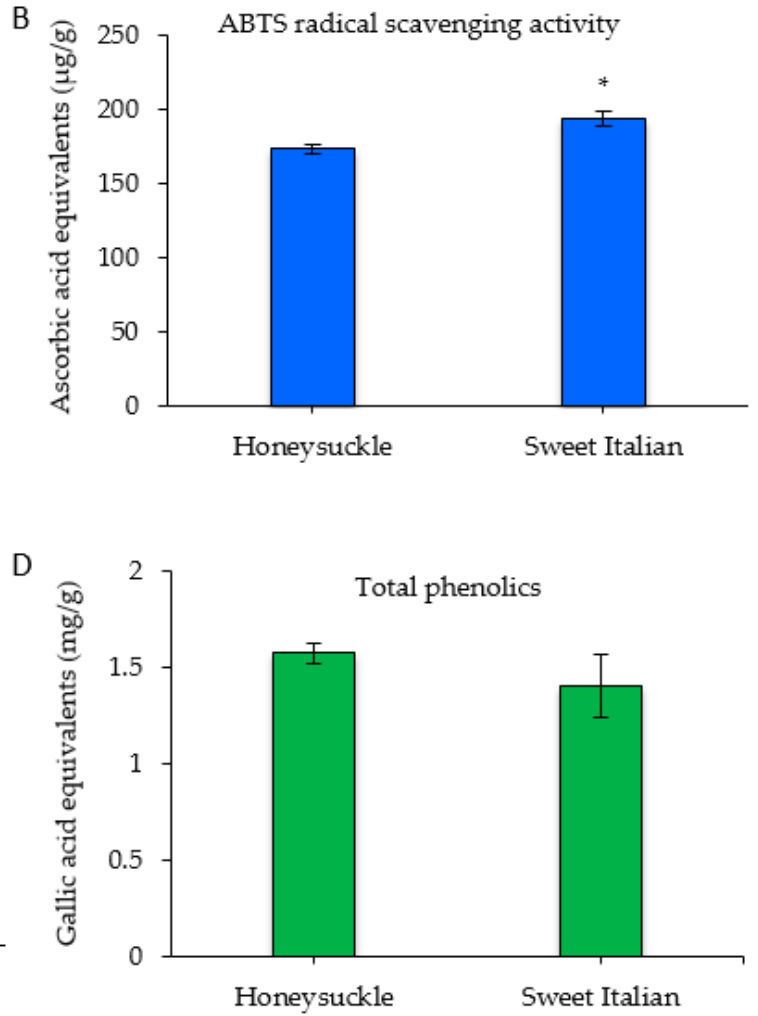

Figure 3. (A) ABTS, (B) DPPH, (C) $\alpha$-amylase activity, and (D) total phenolic content of red onion juice. * Different letters $(a, b, c)$ above the bars of each cultivar indicate statistically significant differences determined by a Student's t-test at $p<0.05$.

Antioxidants can inhibit oxidative reactions and help in the functional performance of enzymes for self-defense mechanisms within the cell [43]. The consumption of onions has been reported to lower the risk of neurodegenerative disease, cancers, cataract formation, and ulcer development due to antioxidant effects [44].

The $\alpha$-amylase activity of red onions was determined and compared with a positive control, acarbose. The inhibition of $\alpha$-amylase showed a significant difference between both the varieties: sweet Italian was high (46.1\%) compared to honeysuckle (Figure 3C). The total phenolic contents of the two varieties are shown in Figure 3D. The content value in honeysuckle was $1.57 \mathrm{mg}$ GAE/g, while sweet Italian was $1.40 \mathrm{mg}$ GAE/g fresh weight. Prakash et al. [45] reported the total phenolic content in the outer, middle, and inner layers of red onion to be 74.1, 15.9, and $5.6 \mathrm{mg} \mathrm{GAE} / \mathrm{g}$ dry weight basis. In another study, Yang et al. reported that the total phenolic content in Northern red onions was $0.815 \mathrm{mg} \mathrm{GAE} / \mathrm{g}$ fresh weight [46].

\subsection{Quantification of Red Onion Flavonoids}

The HPLC-PDA chromatographic separation and elution pattern of different flavonoids are shown in Figure 4A. The identification of onion flavonoids was performed by using LC-HR-ESI-QTOF-MS in positive ionization mode. A total of eight flavonoids was identified, and their tandem mass spectra with + bbCID spectra and the structures of the identified flavonoids are presented in Figures 5 and 6 , respectively. The accurate mass and mass error of the identified onion flavonoids are presented in Table 2. A peak eluted at retention time $\left(t_{R}\right) 10.6 \mathrm{~min}$ showed an accurate mass spectrum at $\mathrm{m} / \mathrm{z} 789.2013$ $[\mathrm{M}+\mathrm{H}]^{+}$(mass error $8.91 \mathrm{ppm}$ ). The precursor ion lost a glucose molecule to give a product ion at $\mathrm{m} / \mathrm{z}$ $465.1010[\mathrm{M}+\mathrm{H}-162-162]^{+}$. 

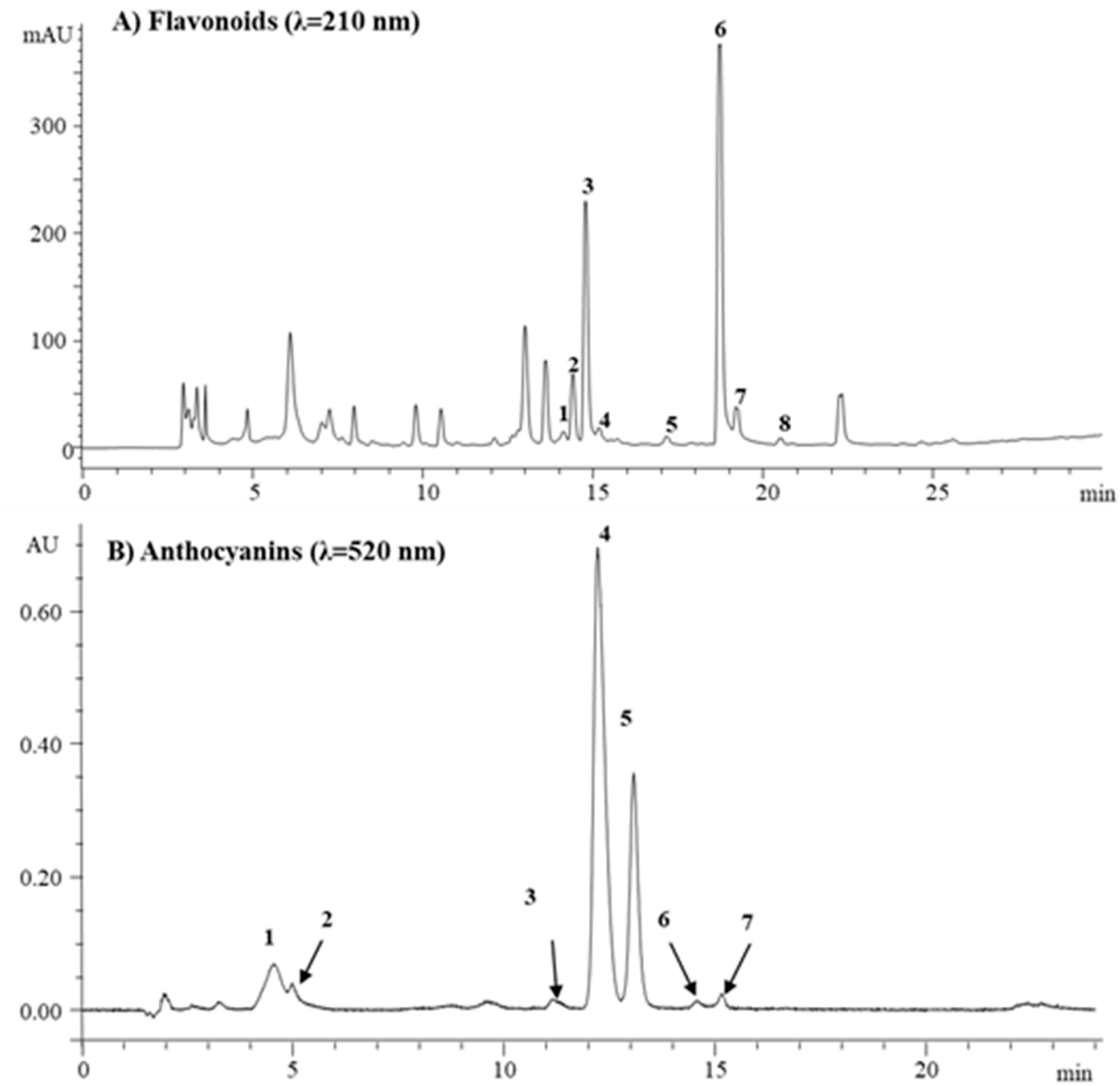

Figure 4. (A) Chromatogram of onion flavanoids. Components 1-8 were identified as follows: 1: Quercetin3,7,4'-triglucoside; 2: Quercetin-7,4'-diglucoside; 3: Quercetin-3,4'-diglucoside; 4: Isorhamnetin-3,4' - diglucoside; 5: Quercetin-3-glucoside; 6: Quercetin-4'-glucoside; 7: Isorhamnetin-4'-glucoside; 8: Quercetin. 4 (B) Chromatogram of onion anthocyanins. Components 1-7 were identified as follows: 1: Cyanidin-3-glucoside; 2: Cyanidin-3-laminaribioside; 3: Delphinidin-3,5-diglucoside; 4: Cyanidin-3-(6"-malonoylglucoside); 5: Cyanidin-3-(6"-malonoyl-laminaribioside); 6: Peonidin-3-malonoylglucoside; 7: Cyanidin-3(malonoyl)(acetyl)-glucoside.

It further lost one glucose molecule to give a prominent base peak at $m / z 303.0481$ [M+H-465-162] $]^{+}$ $\left(\mathrm{Y}_{0}\right)^{+}$with a mass error of $6.03 \mathrm{ppm}$. Thus, the present peak was identified as quercetin-3,7,4'-triglucoside based on the mass spectra and published literature [11]. Another peak eluted at $\left(t_{R}\right) 16.5$ min representing the molecular ion peak at $\mathrm{m} / \mathrm{z} 627.1507[\mathrm{M}+\mathrm{H}]^{+}$(mass error $7.74 \mathrm{ppm}$ ), and aglycone product ion at $\mathrm{m} / \mathrm{z}$ 303.0476 (mass error 7.68 ppm) was recognized as quercetin-7,4'-diglucoside. Similarly, a prominent peak $\left(t_{R} 17.5 \mathrm{~min}\right.$ ) was identified as quercetin-3,4'-diglucoside with an precursor ion at $m / z 627.1527[\mathrm{M}+\mathrm{H}]^{+}$ (mass error $4.44 \mathrm{ppm}$ ) and product ion at $m / z 465.0994[\mathrm{M}+\mathrm{H}-162-162]^{+}$and a aglycone ion at $m / z 303.0491$ $\left(\mathrm{Y}_{0}\right)^{+}$with a mass error $2.73 \mathrm{ppm}$. A minor peak at $\left(\mathrm{t}_{\mathrm{R}}\right) 18.8 \mathrm{~min}$ displayed an accurate mass at $\mathrm{m} / \mathrm{z} 641.1657$ $[\mathrm{M}+\mathrm{H}]^{+}$(mass error $8.5 \mathrm{ppm}$ ). The precursor ion lost two molecules of glucose to give a prominent product ion at $\mathrm{m} / \mathrm{z} 317.0631$ [M+H-162-162] ${ }^{+}$, which was attributed to aglycone isorhamnetin moiety. Thus, the peak at $27.1 \mathrm{~min}$ displayed a similar precursor ion at $\mathrm{m} / \mathrm{z} 465.1012[\mathrm{M}+\mathrm{H}]^{+}$(mass error $3.16 \mathrm{ppm}$ ) and at $\mathrm{m} / \mathrm{z}$ $465.1038[\mathrm{M}+\mathrm{H}]^{+}$(mass error $-2.29 \mathrm{ppm}$ ), respectively. Both precursor ions lost one molecule. 

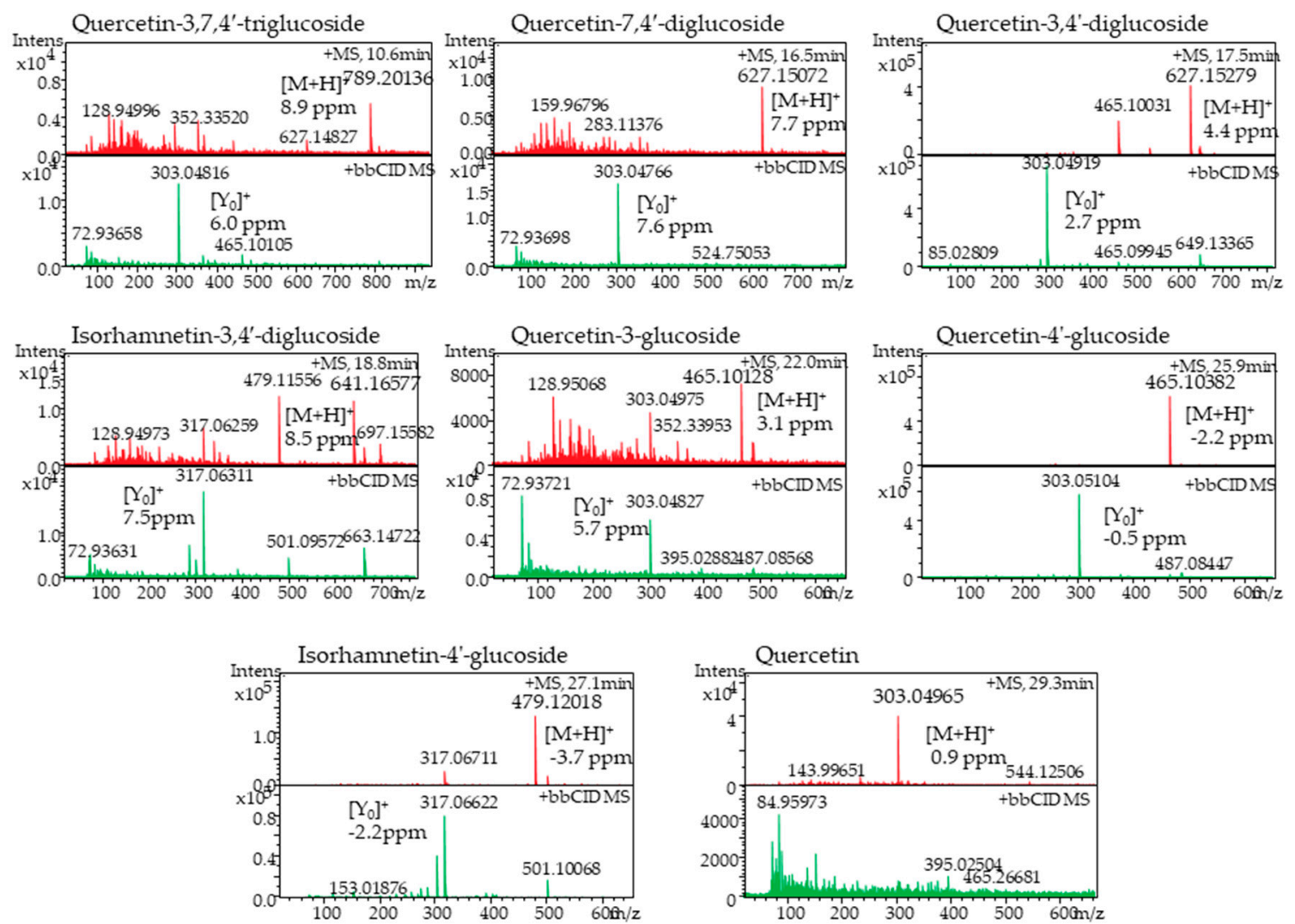

Figure 5. Red onion flavonoids mass spectra identified in positive-ionization mode by LC-HR-ESIQTOF-MS.

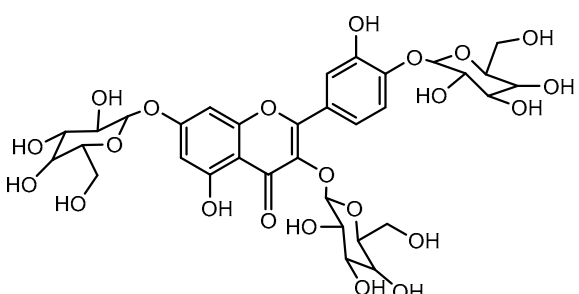

Quercetin 3,7,4'-triglucoside<smiles>COc1cc(-c2oc3cc(O)cc(O)c3c(=O)c2OC(=O)OCCO)ccc1OCC(O)CO</smiles>

Isorhamnetin 3,4'-diglucoside<smiles>O=C(O)C(CO)Oc1c(-c2ccc(O)c(O)c2)oc2cc(O)cc(O)c2c1=O</smiles>

Quercetin-3-glucoside<smiles>COc1cc(-c2oc3cc(O)cc(O)c3c(=O)c2O)ccc1OC(=O)O</smiles>

Isorhamnetin-4'-glucoside<smiles>O=c1c(O)c(-c2ccc(OC(O)CO)c(O)c2)oc2cc(OC(O)CO)cc(O)c12</smiles>

Quercetin 7,4'-diglucoside<smiles>O=c1c(O)c(-c2ccc(OC3OC(CO)C(O)C(O)C3O)c(O)c2)oc2cc(O)cc(O)c12</smiles><smiles>O=c1c(O)c(-c2ccc(O)c(O)c2)oc2cc(O)cc(O)c12</smiles>

Quercetin<smiles>O=C(O)C(O)Oc1ccc(-c2oc3cc(O)cc(O)c3c(=O)c2OCCO)cc1O</smiles>

Quercetin 3,4'-diglucoside
Quercetin-4'-glucoside

Figure 6. Structure of identified flavonoids from red onion. 
Table 2. Identification of flavonoids and anthocyanins in red onions by LC-ESI-QTOF-MS using the positive-ionization mode.

\begin{tabular}{|c|c|c|c|c|c|}
\hline Phytochemical & Compound & $\begin{array}{c}\text { Experimental } \\
\text { MS }(m / z)\end{array}$ & $\begin{array}{c}\text { Theoretical } \\
\text { MS }(m / z)\end{array}$ & $\begin{array}{c}\text { Mass Error } \\
(\mathrm{ppm})\end{array}$ & $\begin{array}{l}\text { Aglycone Ion } \\
(\mathrm{m} / \mathrm{z})\end{array}$ \\
\hline \multirow[t]{8}{*}{ Flavonoids } & Quercetin-3,7,4'-triglucoside & 789.20136 & 789.208399 & 8.9 & 303.04816 \\
\hline & Quercetin-7,4'-diglucoside & 627.15072 & 627.155576 & 7.7 & 303.04766 \\
\hline & Quercetin-3,4'-diglucoside & 627.15279 & 627.155576 & 4.4 & 303.04919 \\
\hline & Isorhamnetin-3,4'-diglucoside & 641.16577 & 641.171226 & 8.5 & 317.06311 \\
\hline & Quercetin-3- glucoside & 465.10128 & 465.102753 & 3.1 & 303.04827 \\
\hline & Quercetin-4'-glucoside & 465.10382 & 465.102753 & -2.2 & 303.05104 \\
\hline & Isorhamnetin- $4^{\prime}$-glucoside & 479.12018 & 479.118403 & -3.7 & 317.06622 \\
\hline & Quercetin & 303.04965 & 303.049929 & 0.9 & - \\
\hline \multirow[t]{7}{*}{ Anthocyanins } & Cyanidin-3-glucoside & 449.1022 & 449.1078 & 12.4 & 287.0516 \\
\hline & Cyanidin-3-laminaribioside & 611.1549 & 611.1606 & 9.3 & 287.0524 \\
\hline & Delphinidin-3,5-diglucoside & 627.1496 & 627.1555 & 9.4 & 303.0474 \\
\hline & Cyanidin-3-(6"-malonoylglucoside) & 535.1024 & 535.1082 & 10.8 & 287.0531 \\
\hline & Cyanidin-3-(6"-malonoyl-laminaribioside) & 697.1532 & 697.161 & 11.1 & 287.0527 \\
\hline & Peonidin-3-malonoylglucoside & 549.1168 & 549.1238 & 12.7 & 301.0665 \\
\hline & Cyanidin-3(malonoyl)-(acetyl)-glucoside & 577.1124 & 577.1187 & 10.9 & 287.0518 \\
\hline
\end{tabular}

Glucose gave a product ion at $m / z 303.0482[\mathrm{M}+\mathrm{H}-162]^{+}$and $m / z 303.0510[\mathrm{M}+\mathrm{H}-162]^{+}$, respectively. Thus, the present peaks were identified as quercetin-3-glucoside and quercetin- $4^{\prime}$-glucoside, respectively. A peak at $\left(\mathrm{t}_{\mathrm{R}}\right) 27.1 \mathrm{~min}$ was identified as isohamnetin- $4^{\prime}$-glucoside with a precursor ion at $\mathrm{m} / \mathrm{z} 479.1201$ $[\mathrm{M}+\mathrm{H}]^{+}$(mass error $-3.70 \mathrm{ppm}$ ) and a product ion at $m / z 317.0662[\mathrm{M}+\mathrm{H}-162]^{+}$. Similarly, the mass spectrum of a minor peak eluted at $\left(\mathrm{t}_{\mathrm{R}}\right) 29.3 \mathrm{~min}$ showed a precursor ion at $\mathrm{m} / \mathrm{z} 303.0496[\mathrm{M}+\mathrm{H}]^{+}$(mass error $0.92 \mathrm{ppm}$ ) which corresponded to the presence of aglycone quercetin in the onion methanol extract.

Table 3 shows the comparative levels of flavonoids, respectively, in the onion cultivars. There was no significant difference between cultivars in these individual flavonoids measured except isorhamnetin- $4^{\prime}$-glucoside and quercetin- $4^{\prime}$-glucoside. Table 3 shows that honeysuckle cultivar had the highest amount of isorhamnetin- $4^{\prime}$-glucoside and quercetin- $4^{\prime}$-glucoside with values of 25.5 and $184.6 \mu \mathrm{g} / \mathrm{g}$ of fresh onions, respectively, as compared to sweet Italian onions with values 13.52 and $115.3 \mu \mathrm{g} / \mathrm{g}$ of fresh onions, respectively.

Table 3. Quantification of flavonoids and anthocyanins in red onions by HPLC.

\begin{tabular}{|c|c|c|c|}
\hline Phytochemical & Compound & Honeysuckle ( $\mu \mathrm{g} / \mathrm{g}$ FW) & Sweet Italian $(\mu \mathrm{g} / \mathrm{g}$ FW) \\
\hline \multirow[t]{9}{*}{ Flavonoids } & Quercetin-3,7,4'-triglucoside & $8.44 \pm 0.95$ & $6.95 \pm 0.47$ \\
\hline & Quercetin-7,4'-diglucoside & $35.34 \pm 1.80$ & $28.73 \pm 1.16$ \\
\hline & Quercetin-3,4'-diglucoside & $168.91 \pm 8.71$ & $154.79 \pm 3.91$ \\
\hline & Isorhamnetin-3,4'-diglucoside & $13.18 \pm 1.56$ & $13.42 \pm 0.53$ \\
\hline & Quercetin-3-glucoside & $5.88 \pm 0.34$ & $6.47 \pm 0.27$ \\
\hline & Quercetin-4'-glucoside & $184.60 \pm 7.11 *$ & $115.14 \pm 3.35$ \\
\hline & Isorhamnetin- $4^{\prime}$-glucoside & $25.58 \pm 1.19 *$ & $13.52 \pm 0.64$ \\
\hline & Quercetin & $7.44 \pm 0.59$ & $6.31 \pm 0.35$ \\
\hline & Total Flavonoids & $449.37 \pm 75.21 *$ & $345.34 \pm 58.09$ \\
\hline \multirow[t]{8}{*}{ Anthocyanins } & Cyanidin-3-glucoside & $6.42 \pm 0.94$ & $9.30 \pm 1.77$ \\
\hline & Cyanidin-3-laminaribioside & $5.34 \pm 0.49 *$ & $3.03 \pm 0.67$ \\
\hline & Delphinidin-3,5-diglucoside & $1.25 \pm 0.08$ & $1.07 \pm 0.19$ \\
\hline & Cyanidin-3-(6"-malonoylglucoside) & $58.88 \pm 3.76$ & $50.90 \pm 6.79$ \\
\hline & Cyanidin-3-(6"-malonoyl-laminaribioside) & $30.18 \pm 2.14$ * & $20.44 \pm 2.84$ \\
\hline & Peonidin-3-malonoylglucoside & $1.01 \pm 0.08 *$ & $0.66 \pm 0.12$ \\
\hline & Cyanidin-3(malonoyl)-(acetyl)-glucoside & $0.33 \pm 0.09$ & $1.05 \pm 0.35^{*}$ \\
\hline & Total Anthocyanins & $103.40 \pm 22.06$ & $86.47 \pm 18.43$ \\
\hline
\end{tabular}

Values are mean \pm standard deviation of three samples; ${ }^{*}$ indicate significant difference between two cultivars as determined by students $t$-test at $p<0.05$.

In our study, we found that quercetin-3, $4^{\prime}$-diglucoside and quercetin- $4^{\prime}$-glucoside were the most abundant flavonoids, and these results are in agreement with the previous studies $[11,19,47]$. Overall, the total flavonoids were higher in honeysuckle cultivar $(440.93 \mu \mathrm{g} / \mathrm{g})$ than sweet Italian $(338.39 \mu \mathrm{g} / \mathrm{g})$. Serban et al. [48] reported the quercetin effect on blood pressure in 7 trials comprising 9 treatment arms (587 patients). The authors reported that supplementation with quercetin $>500 \mathrm{mg} /$ day causes 
significant reductions in both systolic and diastolic blood pressure. Quercetin glucosides possess antioxidant, anti-inflammatory, cardioprotective, and anti-allergic properties. Quercetin also reduces the risk of clot formation near the damaged endothelium [49].

\subsection{Identification and Quantitation of Anthocyanins}

In the present study, seven anthocyanins were identified using LC-HR-ESI-QTOF-MS in positive ionization mode. The protonated accurate mass and mass error of the identified anthocyanins are presented in Table 2. The tandem mass spectra with +bbCID spectra and the structures were identified.

Anthocyanins are presented in Figures 7 and 8, respectively. A peak eluted at retention time $\left(t_{R}\right) 13.5$ min exhibited a UV spectrum at $520 \mathrm{~nm}$, which corresponded to characteristic flavylium cation. A MS spectrum showed an accurate mass at $m / z 449.1022[\mathrm{M}]^{+}$(mass error $12.4 \mathrm{ppm}$ ). The precursor ion lost a glucose molecule to give a product ion at $m / z 287.0516$ [M-162] $^{+}$(mass error $11.8 \mathrm{ppm}$ ), which corresponded to the aglycone moiety. Thus, based on the MS and +bbCID mass spectra, UV-Vis-spectra, and published literature [50-52], the present peak was identified as cyanidin-3-glucoside. Similarly, another peak eluted at $t_{R} 15.8$ min represented the molecular ion peak at $m / z 611.1549$ [M] $^{+}$(mass error $9.3 \mathrm{ppm}$ ) and product ion at $m / z 287.0524$ [M-162-162] $^{+}$(mass error $^{2}$ $9.0 \mathrm{ppm}$ ) was identified as cyanidin-3-laminaribioside.
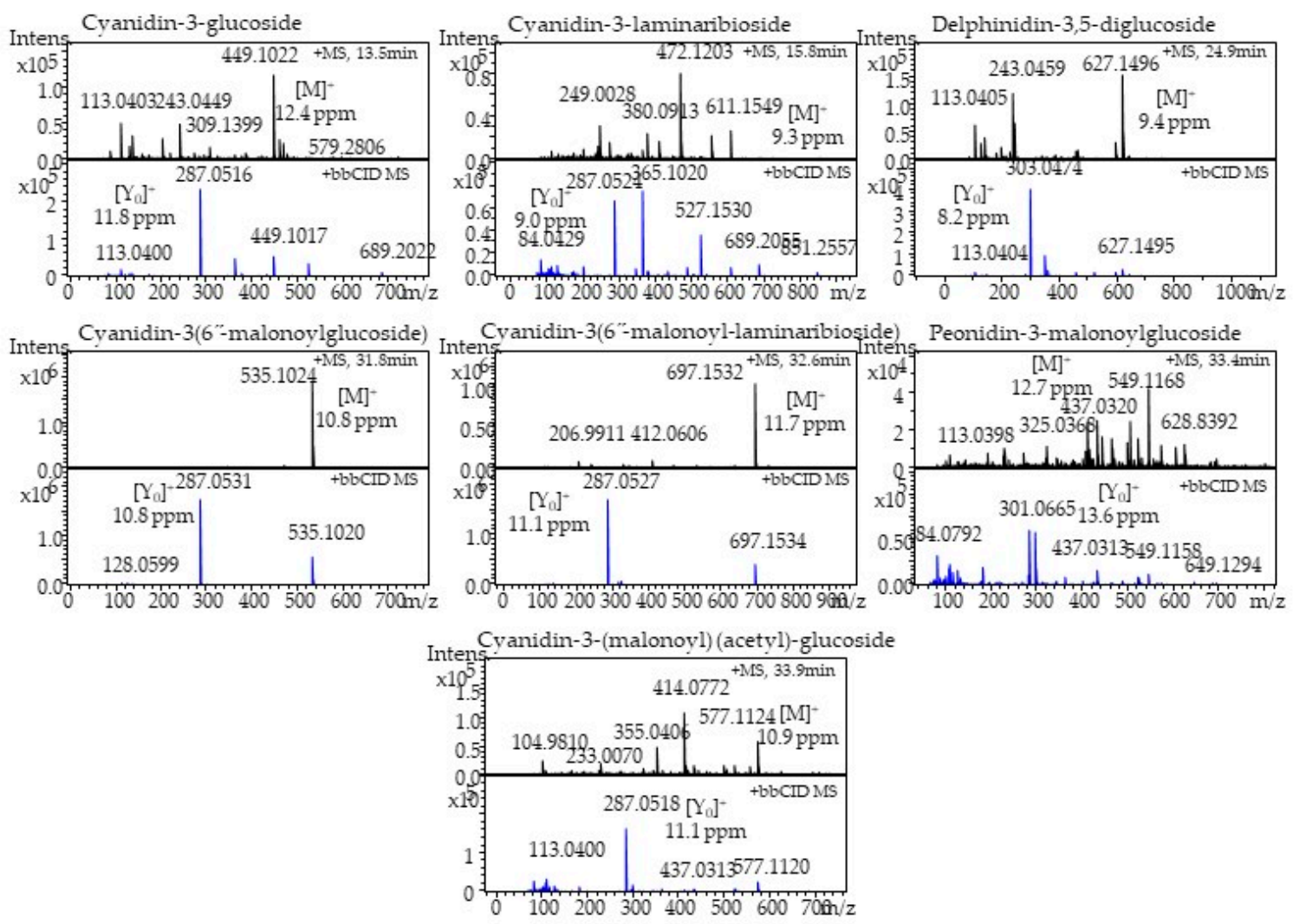

Figure 7. Seven major anthocyanins identified from red onion by LC-HR-ESI-QTOF-MS. 
<smiles>OCC(O)COc1cc2c(O)cc(O)cc2[o+]c1-c1ccc(O)c(O)c1</smiles>

Cyanidin-3-glucoside<smiles>O=C(O)CC(=O)OCC(O)Oc1cc2c(O)cc(O)cc2[o+]c1-c1ccc(O)c(O)c1</smiles>

Cyanidin-3-(6"-malonoylglucoside)

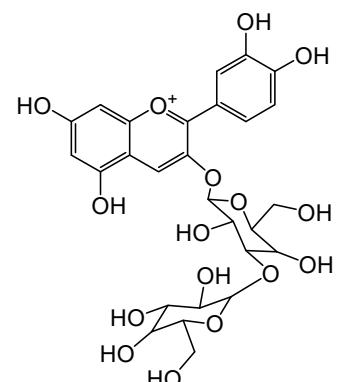

Cyanidin-3-laminaribioside<smiles>O=C(O)CC(=O)OCC(O)COc1cc2c(O)cc(O)cc2[o+]c1-c1ccc(O)c(O)c1</smiles>

Cyanidin-3-(6"-malonoyllaminaribioside)

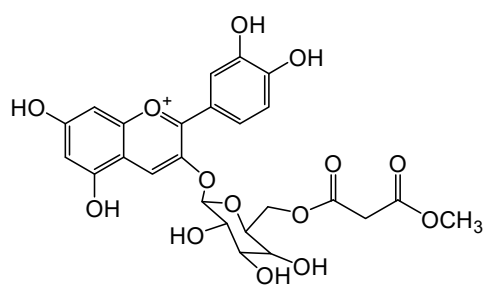

Cyanidin 3-(malonoyl) (acetyl)-glucoside

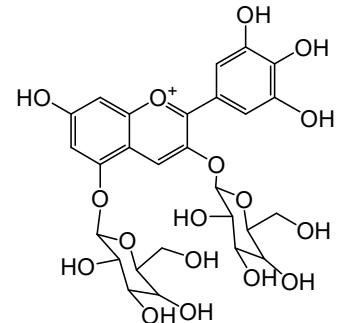

Delphinidin-3,5-diglucoside<smiles></smiles>

Peonidin-3-(6-malonyl)-glucoside

Figure 8. Structure of identified anthocyanins from red onions.

HR-QTOF-MS spectra of the precursor ion ( $\mathrm{t}_{\mathrm{R}} 24.9 \mathrm{~min}$ ) showed an accurate mass at $\mathrm{m} / \mathrm{z} 627.1496$ $[\mathrm{M}]^{+}$(mass error $9.4 \mathrm{ppm}$ ). The precursor ion lost two molecules of glucose to give a prominent product ion peak at $\mathrm{m} / \mathrm{z} 303.0474$ [M-162-162] $^{+}$(mass error $8.2 \mathrm{ppm}$ ), which was attributed to aglycone delphinidin moiety. Thus, the present peak was identified as delphinidin-3,5-diglucoside. Two peaks eluted at 31.8 and 32.6 min displayed a molecular ion at $m / z 535.1024[\mathrm{M}]^{+}$(mass error $10.8 \mathrm{ppm}$ ) and at $m / z 697.1532[\mathrm{M}]^{+}$(mass error $11.7 \mathrm{ppm}$ ), respectively. Both peaks were identified as cyanidin derivatives. A peak $\left(\mathrm{t}_{\mathrm{R}} 31.8 \mathrm{~min}\right.$ ) showed a prominent product ion at $\mathrm{m} / \mathrm{z} 287.0531$ [M-162-86] ${ }^{+}$ (mass error $10.8 \mathrm{ppm}$ ) due to the loss of glucose and a malonyl moiety. Similarly, another peak $\left(t_{\mathrm{R}} 32.6 \mathrm{~min}\right.$ ) lost two molecules of glucose and a malonyl moiety and displayed an intense base peak at $\mathrm{m} / \mathrm{z} 287.0527$ [M-162-162-86 $]^{+}$(mass error $11.1 \mathrm{ppm}$ ). Thus, the present peaks were identified as cyanidin-3-(6"-malonylglucoside) and cyanidin-3-(6"-malonyl-laminaribioside), respectively.

A minor peak ( $\left.\mathrm{t}_{\mathrm{R}} 33.4 \mathrm{~min}\right)$ was identified as peonidin-3-malonylglucoside with a precursor ion at $\mathrm{m} / z 549.1168[\mathrm{M}]^{+}$(mass error $12.7 \mathrm{ppm}$ ) and a product ion at $\mathrm{m} / \mathrm{z} 301.0665$ [M-162-86] $^{+}$(mass error $13.6 \mathrm{ppm}$ ). The MS and +bbCID spectra of the peak eluted at $t_{\mathrm{R}} 33.9 \mathrm{~min}$ displayed a precursor ion at $\mathrm{m} / \mathrm{z} 577.1124[\mathrm{M}]^{+}$with a mass error of $10.9 \mathrm{ppm}$. The product ion was at $\mathrm{m} / \mathrm{z} 287.0518$ [M-162-86-42] $]^{+}$.

The mass error $11.1 \mathrm{ppm}$ was yielded with a loss of glucose, malonly, and acetyl molecules. On the basis of the accurate mass, fragmentation pattern, and literature reports, the present peak was identified as cyanidin-3-(malonyl)-(acetyl)-glucoside.

Figure $4 \mathrm{~B}$ and Table 3 show the HPLC chromatograph and comparative levels of anthocyanins, respectively, in the onion cultivars. Cyanidin-3-(6"-malonyl-laminaribioside), cyanidin-3-laminaribioside, 
and peonidin-3-malonoylglucoside, which were $30.1 \pm 2.1 \mu \mathrm{g} / \mathrm{g}, 5.3 \pm 0.4 \mu \mathrm{g} / \mathrm{g}$, and $1.0 \pm 0.08 \mu \mathrm{g} / \mathrm{g}$, respectively, were significantly higher in honeysuckle onion. The total anthocyanin content was higher in honeysuckle (103 $\mu \mathrm{g} / \mathrm{g}$ FW) than sweet Italian ( $86 \mu \mathrm{g} / \mathrm{g}$ FW). Other authors, such as Pérez-Gregorio et al. [53], Ferreres et al. [54], and Gennaro et al. [55], reported the total anthocyanins in red onions to be 28.68, 233, and $90 \mu \mathrm{g} / \mathrm{g}$, respectively. Anthocyanins exert different biological effects, and consumption of food rich in anthocyanins may be useful for antidiabetic, anti-obesity, neuroprotective agents, cardiovascular protection, and inhibiting cancer growth [56].

\subsection{Principal Component Analysis and Pearson's Correlation Coefficients}

The principal component analysis (PCA) model was applied to determine the essential variables that separate the cultivars of sweet red onion. The first (PC1) and the second (PC2) components explained $40 \%$ and $23.3 \%$ of the total variance, respectively (Figure 9). PCA grouped samples into two cultivars that reflected marked differences in the phytochemical depending on the cultivar. The corresponding biplot emphasized that the separation between the two cultivars was characterized by flavonoids, anthocyanins, sucrose, total phenolic content, DPPH, and minerals ( $\mathrm{Ca}, \mathrm{Na}, \mathrm{B}, \mathrm{Cu}, \mathrm{Zn})$ which were high in honeysuckle red onions. However, the amount of pyruvic acid contributed to the distinction between the two cultivars.

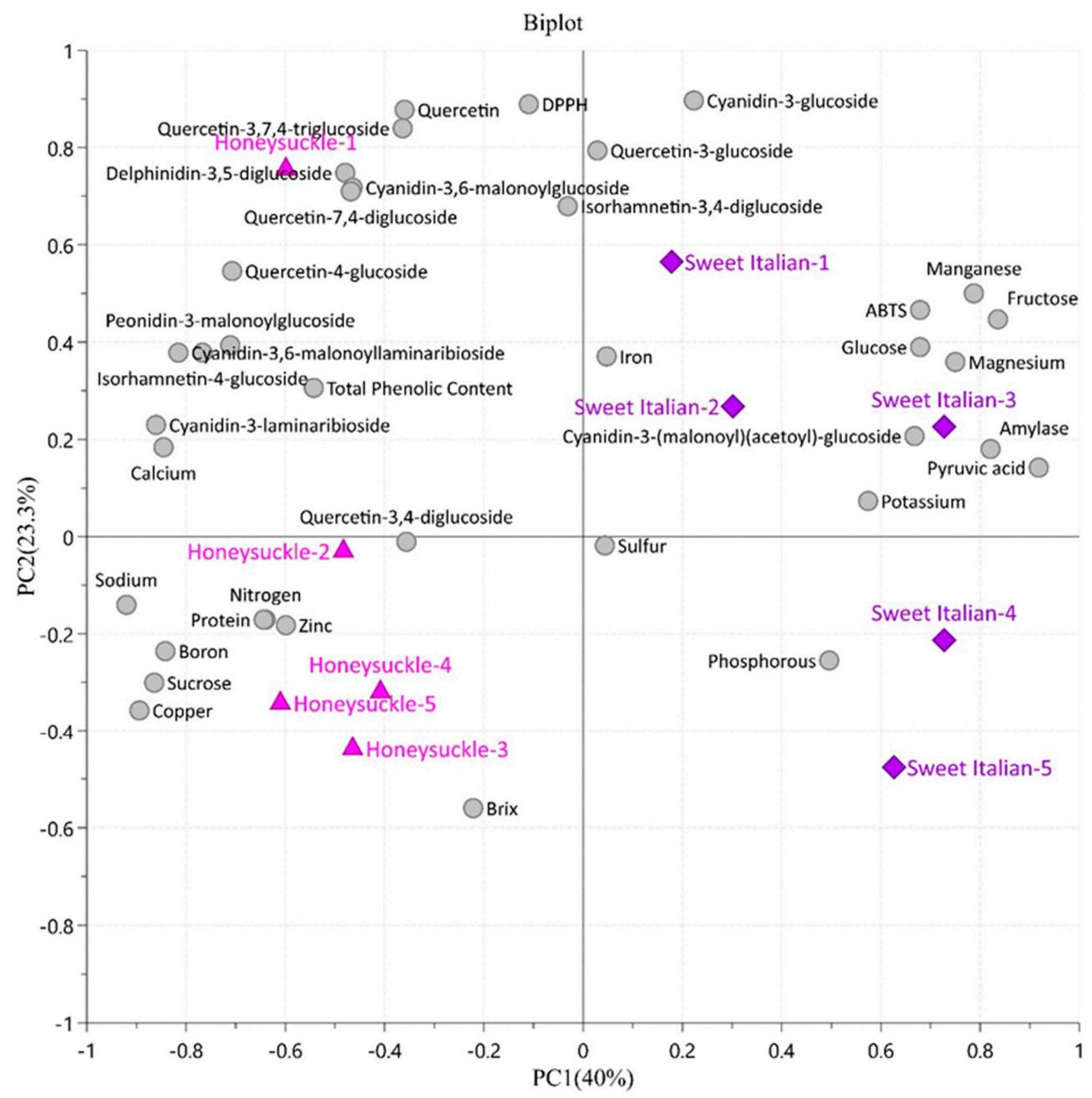

Figure 9. The biplot obtained from principal component analysis (PCA) describing the variation between honeysuckle and sweet Italian red onion cultivars and the correlation with the phytochemicals. The phytochemicals are represented as gray dots, and the cultivars are represented with the triangle (pink) and diamond (purple) markers. 
To seek the correlation between phytochemical contents and antioxidant activities, Pearson's correlation coefficient was observed (Supplementary Table S1). DPPH showed a high positive correlation with quercetin, quercetin-7,4'-diglucoside, quercetin-3,7,4'-triglucoside, quercetin-3-glucoside, quercetin-4-glucoside, and isorhamnetin-3,4-diglucoside ( $\mathrm{r}>0.70,0.75,0.77$, $0.55,0.54$, and 0.64 respectively). The protective effect of flavonoids is due to their capacity to transfer hydrogen free radicals, act as scavengers of free radicals, activate the antioxidant enzyme, and inhibit oxidases [57]. The antioxidant activity of quercetin-3-glucoside and quercetin- $4^{\prime}$-glucoside on iron ion-driven lipid peroxidation of the gastrointestinal mucosa in rats was studied. In this study, the rat gastrointestinal mucosa homogenates were incubated with $\mathrm{Fe}(\mathrm{NO} 3)_{3}$, ascorbic acid, quercetin, and its glucoside where quercetin- 4 '-glucoside suppressed the mucosal lipid peroxidation, which turned out to be favorable antioxidant sources [58]. Anthocyanin such as delphinidin-3,5-diglucoside, cyanidin-3,6-malonoylglucoside, and cyanidin-3-glucoside was strongly correlated with DPPH with Pearson coefficient of 0.75 . Cyanidin-3-glucoside possesses strong antioxidant activity due to two hydroxyls on the B-ring, and recent studies support its bioactivity as DNA-RSC, gastroprotective, anti-inflammatory, antithrombotic, chemopreventive, and as an epigenetic factor [59]. Li et al. reported the protective effect of cyanidin-3-glucoside by lowering the cardiovascular complications on type 2 diabetes rat model [60]. Similarly, a glucoside derivative of cyanidin showed significant inhibition of $\alpha$-amylase and sucrase enzymes which may help in the prevention of diabetic complications [61]. Our result shows that the correlation between $\alpha$-amylase and cyanidin-3-glucoside was found to be 0.45 . In addition, the quercetin and anthocyanin derivatives were slightly correlated to the total phenolics $(<0.5)$. On the other hand, ABTS was weakly associated with the quercetin derivatives and anthocyanins group.

\section{Material and Methods}

\subsection{Plant Materials and Chemicals}

Honeysuckle red onions from J \& D Produce, Inc., Texas and Artisan sweet Italian red onions from Tanimura \& Antle, California were used for the entire study (Figure 1). Sodium pyruvate, 2, 4-dinitrophenylhydrazine (DNPH), glucose, sucrose, fructose, quercetin 3-glucoside, Quercetin-3,4'-diglucoside, quercetin, delphinidin 3-glucoside, L-ascorbic acid, gallic acid, dextrose, sodium carbonate, 2,2-diphenyl-1-picryhydrazyl, 2,2'-azino-bis-(3-ethylbenzothiazoline-6-sulphonic acid), Folin-Ciocalteu reagent, HPLC grade methanol, acetonitrile, formic acid, and metaphosphoric acid were purchased from Sigma Aldrich (St. Louis, MO, USA). Sodium hydroxide ( $\mathrm{NaOH}$ ) was obtained from Fisher Scientific (Pittsburg, PA, USA).

\subsection{Pyruvic Acid Content}

The neck, basal plate, and skin of the onion bulbs were removed and blended to extract onion juice. The pyruvic acid content in the onion juice was recorded by an automated dinitrophenyl hydrazine method previously developed by our group $[62,63]$. Soluble solid content (SSC) was measured in the juice using a refractometer and expressed as ${ }^{\circ}$ Brix.

\subsection{Sugar Analysis}

The sucrose, glucose, and fructose were analyzed using HPLC and an RI detector. A total of $20 \mu \mathrm{L}$ of the sample was injected into the HPLC system which was connected to a binary pump (Perkin Elmer LC-200, Norwalk, CT, USA), an autosampler (Perkin Elmer LC-200), a refractive index-150 detector (SystemSpectra), and a carbohydrate column Rezex ${ }^{\mathrm{TM}} \mathrm{RCM}-\mathrm{Monosaccharide} \mathrm{Ca}^{2+}(8 \%)$ of $300 \times 7.8 \mathrm{~mm}$ (Phenomenex, Torrance, CA, USA) equipped with a guard cartridge. The column temperature was maintained at $80^{\circ} \mathrm{C}$ using a column heater (Jones chromatography, Lakewood, $\mathrm{CO}$, USA). The water was used as a solvent at a flow rate of $0.6 \mathrm{~mL} / \mathrm{min}$ that was degassed using degasser 
(Gastorr TG-14). Sugar concentrations were calculated using standard curves for sucrose, glucose, and fructose ranging from 1.25 to $20 \mathrm{mg} / \mathrm{mL}$.

\subsection{Protein and Mineral Analysis}

Approximately $45 \mathrm{~g}$ pulp was stored at $-80^{\circ} \mathrm{C}$ for $24 \mathrm{~h}$ and lyophilized (Labconco Freeze-Dryer, Kansas City, MO, USA) for two days to obtain the dried powder. The dried samples were weighed, and the protein and mineral content was measured at the Texas AgriLife Extension Soil, Water, and Forage Testing Laboratory. Inductive coupled plasma-atomic emission spectroscopy (ICP-AES) (Spectro Genesis, Deutschland, Germany) was used to estimate the mineral content of onion.

\subsection{Analysis of Total Phenolic Content, Antioxidant Capacity, and $\alpha$-Amylase Assay}

Total phenolics, DPPH, and ABTS radical scavenging activity of both onion cultivars were determined using our previously published methods $[64,65]$. Fresh onion samples $(15 \mathrm{~g})$ were extracted twice with $15 \mathrm{~mL}$ methanol. The extracts were pooled together and further used for quantification of total phenolics and free radical scavenging activities. All standards and samples were pipetted in triplicate into 96 well plates separately. The absorbance was measured using Synergy ${ }^{\mathrm{TM}}{ }^{\mathrm{HT}}$ Multi-Mode Microplate Reader (BioTek, Instruments, Winooski, VT, USA) at 760, 515, and $734 \mathrm{~nm}$ for total phenolics, $\mathrm{DPPH}$, and ABTS assays, respectively. The results of total phenolics were expressed as mg gallic acid equivalent/gram of fresh weight of samples, and radical scavenging activities were expressed as $\mathrm{mg}$ ascorbic acid equivalent/gram of dry weight sample.

The $\alpha$-amylase inhibitory activity was measured using a published protocol with minor modifications [66]. Dextrose was used to prepare a standard curve at different concentrations. Acarbose was used as a positive control and methanol as a negative control to calculate the percentage inhibition.

\subsection{Analysis of Flavonoids}

Onion pulp (10 mg) was weighed and extracted with $20 \mathrm{~mL}$ methanol, vortexed for $15 \mathrm{~s}$, sonicated for $30 \mathrm{~min}$, and then centrifuged at $4480 \times g$ for $10 \mathrm{~min}$. After decanting the filtrate, the residue was re-extracted with $20 \mathrm{~mL}$ methanol followed by the above procedure. The two extracts were combined, filtered, and transferred to an amber HPLC vial. An Agilent 1200 Series HPLC (Agilent, Foster City, CA, USA) system consisting of a degasser, quaternary pump, autosampler, column oven, and a diode array detector. The separation was carried out using an RP C18 Gemini series column $(250 \times 4.6 \mathrm{~mm}$; $5 \mu \mathrm{m}$ ) (Phenomenex, Torrence, CA, USA). A $5 \mu \mathrm{L}$ sample was injected into the column with a flow rate of $0.8 \mathrm{~mL} / \mathrm{min}$, the oven temperature was set at $35^{\circ} \mathrm{C}$, and the peaks were monitored at 210 and $280 \mathrm{~nm}$ with a run time of $30 \mathrm{~min}$. The elution was carried out using gradient mode elution with acetonitrile (A) and $0.03 \mathrm{M}$ phosphoric acid (B). Initially, elution was carried out at $98-75 \% \mathrm{~B}$ for (0-12 $\mathrm{min}$ ), followed by $75-45 \%$ B (12-22 $\mathrm{min}), 45-5 \%$ B (22-26 $\mathrm{min}), 5-98 \%$ B (26-29 $\mathrm{min}$ ) and returned to $98 \% \mathrm{~B}$ at $30 \mathrm{~min}$. The column was equilibrated for 2 min before the next injection. Quantification of flavonoids was carried out using standards quercetin-3-glucoside, quercetin-3,4'-diglucoside, and quercetin. Flavonoid results were expressed as $\mu \mathrm{g} / \mathrm{g}$ of fresh weight of the sample.

\subsection{LC-HR-ESI-QTOF-MS Identification of Flavonoids}

Flavonoids were identified in onion extract using Agilent 1290 liquid chromatography (Santa Clara, CA, USA) coupled to a maXis Impact high-resolution mass spectrometer (Bruker Daltonics, Billerica, MA, USA) according to our published paper [67]. Briefly, a chromatographic resolution was achieved by column Zorbax Eclipse plus $(1.8 \mu \mathrm{m} ; 50 \times 2.1 \mathrm{~mm})$ with a gradient solvent system, (A) $0.1 \%$ formic acid in water, and (B) $0.1 \%$ formic acid in acetonitrile with a flow rate of $0.2 \mathrm{~mL} / \mathrm{min}$ at $30{ }^{\circ} \mathrm{C}$. Elution of flavonoids was performed by programming as follows: $2-25 \%$ B (12 $\mathrm{min}), 25-55 \% \mathrm{~B}$ (11 min), $55-98 \% \mathrm{~B}(4 \mathrm{~min}), 98-2 \% \mathrm{~B}(2 \mathrm{~min})$, and $2 \mathrm{~min}$ isocratic at $2 \% \mathrm{~B}$. The injection volume was $1 \mu \mathrm{L}$ and postrun equilibrium was $1 \mathrm{~min}$. Mass spectral analysis was performed by electrospray ionization (ESI) in positive ionization mode. Mass spectra (MS) and broadband collision-induced dissociation (bbCID) 
acquisition were acquired in the $m / z$ 50-2000 scan range. Nitrogen was used as a nebulizer and drying gas. A nebulizer gas pressure and drying temperature was $3.2 \mathrm{bar}$ and $250{ }^{\circ} \mathrm{C}$, respectively, and the capillary voltage was kept at $3500 \mathrm{~V}$. The external calibration of the mass spectrometer was performed by sodium formate solution clusters using the high-precision calibration mode. Software Data Analysis 4.3 was used for the determination of accurate mass for the molecular ions and precursors ions.

\subsection{Analysis of Anthocyanins}

Anthocyanin extraction was performed according to published paper [68]. Freshly cut red onion (10 g) was extracted with acidic methanol (1\% formic acid). The sample was homogenized (1 min), sonicated for $30 \mathrm{~min}$, and centrifuged at $7826 \times g$ under dark conditions. The supernatant was transferred to the new tubes, and residue was re-extracted twice with acidic methanol. All the supernatants were pooled, volume was measured, and the sample was kept at $-80{ }^{\circ} \mathrm{C}$ for further analysis.

Anthocyanins were analyzed by using Waters 1525 HPLC (Milford, MA, USA) equipped with a 717 plus autosampler and a 2996 photodiode array detector (PDA). Anthocyanin separations were achieved by a Zorbax Eclipse plus C18 ODS column $(250 \times 4.6 \mathrm{~mm})$ with particle size of $5 \mu \mathrm{m}$ (Agilent, Santa Clara, CA). The mobile phase consisted of (A) $0.03 \mathrm{M}$ phosphoric acid in water and (B) acetonitrile/water $(50: 50, v / v)$ with a flow rate of $0.6 \mathrm{~mL} / \mathrm{min}$. The gradient elution was as follows: $25 \%$ B isocratic ( $3 \mathrm{~min}), 25-40 \%$ B (7 min), 40\% B isocratic ( $6 \mathrm{~min}), 40-80 \%$ B ( $2 \mathrm{~min}), 80-25 \%$ B ( $2 \mathrm{~min}$ ), and $25 \% \mathrm{~B}$ isocratic $(4 \mathrm{~min})$. The chromatogram was acquired at $520 \mathrm{~nm}$, and data were processed by Empower-2 software. Anthocyanins were expressed as $\mu \mathrm{g} / \mathrm{g}$ of fresh weight of the sample.

\subsection{LC-HR-ESI-QTOF-MS Identification of Onion Anthocyanins}

Anthocyanins were analyzed by 1290 Agilent LC system (Agilent, Santa Clara, CA, USA). A C18 column, rapid resolution high definition (RRHD) Zorbax Eclipse plus $(1.8 \mu \mathrm{m} ; 50 \times 2.1 \mathrm{~mm})$ (Agilent, Santa Clara, CA, USA), was used for the chromatographic separation. The gradient mobile phase consisted of A) $0.1 \%$ formic acid in water and (B) $0.1 \%$ formic acid in acetonitrile. Mass spectral analysis was performed according to the published papers [69]. Briefly, a maXis impact mass spectrometer (Bruker Daltonics, Billerica, MA) was used for obtaining the mass spectra in ESI in positive ionization mode. MS and bbCID data were obtained at $m / z$ 50-2000 scan range. Nitrogen was used as a nebulizer (gas pressure of $2.1 \mathrm{bar}$ ) and drying gas $(8.0 \mathrm{~L} / \mathrm{min})$. The capillary ion voltage was $4500 \mathrm{~V}$, and the drying gas temperature was $250^{\circ} \mathrm{C}$. External mass spectrometer calibration was performed by sodium formate solution. The determination of accurate mass data for the molecular ions was performed using the software Data Analysis 4.3.

\subsection{Statistical Data}

Each onion variety had 15 bulbs of an average weight of $170 \mathrm{~g}$ and was divided into five groups. The analysis was carried out on five grouped samples belonging to each onion variety. Each experiment was performed in triplicate, and all data are presented as the mean \pm SD. Analysis of variance (ANOVA) was carried out using JMP pro 14 software. Excel software was used to prepare graphs, and multiple mean comparisons ( $p$ value $<0.05$ ) were carried out by a Student's $t$-test. Principal component analysis (PCA) was performed by SIMCA-P+ software (version 16, Umetrics AB, Umea, Sweden) using the Pareto scaling method.

\section{Conclusions}

This study provides information describing the nutritional values in honeysuckle and sweet Italian red onions. The pungency of honeysuckle was lower than the artisan onions. The total flavonoid for honeysuckle and artisan onions was 449 and $345 \mu \mathrm{g} / \mathrm{g} \mathrm{FW}$, respectively. The total anthocyanin for honeysuckle onion was $103 \mu \mathrm{g} / \mathrm{g} \mathrm{FW}$, while for artisan onion was $86 \mu \mathrm{g} / \mathrm{g}$ FW. Honeysuckle onions showed relatively high levels of calcium, sodium, zinc, and copper along with nitrogen and protein content. The results indicated that the total flavonoids, total phenolic content, total anthocyanins, 
protein, and calories for honeysuckle onions were higher than the artisan onions. The PCA model was applied to all data to determine the most important variables that separate the cultivars of red onion. Pearson's correlation coefficients among quercetin derivatives and DPPH were higher than 0.7; while, quercetin derivatives and total phenolics were 0.5. Overall, these findings suggest that these varieties are good for consumption, with most of the nutritional values required for the human diet.

Supplementary Materials: The following are available online at http://www.mdpi.com/2223-7747/9/9/1077/s1: Table S1: the correlation between phytochemical contents and antioxidant activities; Pearson's correlation coefficient.

Author Contributions: Conceptualization, G.K.J. and B.S.P.; data curation, R.M. and J.S.; funding acquisition, B.S.P.; supervision, G.K.J. and B.S.P.; writing—original draft, R.M. and J.S.; writing-review and editing, R.M., J.S., P.A., and G.K.J. All authors have read and agreed to the published version of the manuscript.

Funding: This research was funded by the United States Department of Agriculture-NIFA-SCRI-2017-51181-26834 through the National Center of Excellence for Melon at the Vegetable and Fruit Improvement Center of Texas A\&M University.

Conflicts of Interest: The authors declare no conflict of interest.

\section{References}

1. Sellappan, S.; Akoh, C.C. Flavonoids and antioxidant capacity of Georgia-grown Vidalia onions. J. Agric. Food Chem. 2002, 50, 5338-5342. [CrossRef]

2. Lombard, K.; Peffley, E.; Geoffriau, E.; Thompson, L.; Herring, A. Quercetin in onion (Allium cepa L.) after heat-treatment simulating home preparation. J. Food Compos. Anal. 2005, 18, 571-581. [CrossRef]

3. US Department of Agriculture, \& Economic Research Service. (April 12, 2020). Per Capita Consumption of Fresh Onions in the United States from 2000 to 2019 (in Pounds). Statista. Available online: https://www.statista.com/statistics/257306/per-capita-consumption-of-fresh-onions-in-the-us/ (accessed on 12 August 2020).

4. Yoo, K.S.; Lee, E.J.; Patil, B.S. Changes in flavor precursor, pungency, and sugar contents in shortday onion bulbs during five month storage at various temperatures and controlled-atmosphere. J. Food Sci. 2012, 77, C216-C221. [CrossRef]

5. Hossain, M.B.; Lebelle, J.; Birsan, R.; Rai, D.K. Enrichment and Assessment of the Contributions of the Major Polyphenols to the Total Antioxidant Activity of Onion Extracts: A Fractionation by Flash Chromatography Approach. Antioxidants 2018, 7, 175. [CrossRef]

6. Manach, C.; Scalbert, A.; Morand, C.; Rémésy, C.; Jiménez, L. Polyphenols: Food sources and bioavailability. Am. J. Clin. Nutr. 2004, 79, 727-747. [CrossRef]

7. Slimestad, R.; Fossen, T.; Vågen, I.M. Onions: A source of unique dietary flavonoids. J. Agric. Food Chem. 2007, 55, 10067-10080. [CrossRef]

8. Sytar, O. Phenolic acids in the inflorescences of different varieties of buckwheat and their antioxidant activity. J. King Saud Univ. Sci. 2015, 27, 136-142. [CrossRef]

9. Kaushik, P.; Andújar, I.; Vilanova, S.; Plazas, M.; Gramazio, P.; Herraiz, F.J.; Brar, N.S.; Prohens, J. Breeding vegetables with increased content in bioactive phenolic acids. Molecules 2015, 20, 18464-18481. [CrossRef]

10. Kaur, C.; Joshi, S.; Kapoor, H. Antioxidants in onion (Allium Cepa L.) cultivars grown in India. J. Food Biochem. 2009, 33, 184-200. [CrossRef]

11. Søltoft, M.; Christensen, J.H.; Nielsen, J.; Knuthsen, P. Pressurised liquid extraction of flavonoids in onions. Method development and validation. Talanta 2009, 80, 269-278. [CrossRef]

12. Rajeswari, G.; Susanna, S.; Prabhasankar, P.; Venkateswara Rao, G. Influence of onion powder and its hydrocolloid blends on pasta dough, pasting, microstructure, cooking and sensory characteristics. Food Biosci. 2013, 4, 13-20. [CrossRef]

13. Nishimura, M.; Muro, T.; Kobori, M.; Nishihira, J. Effect of Daily Ingestion of Quercetin-Rich Onion Powder for 12 Weeks on Visceral Fat: A Randomised, Double-Blind, Placebo-Controlled, Parallel-Group Study. Nutrients 2020, 12, 91. [CrossRef]

14. Brglez Mojzer, E.; Knez Hrnčič, M.; Škerget, M.; Knez, Ž.; Bren, U. Polyphenols: Extraction methods, antioxidative action, bioavailability and anticarcinogenic effects. Molecules 2016, 21, 901. [CrossRef] 
15. Nile, S.H.; Park, S.W. Total phenolics, antioxidant and xanthine oxidase inhibitory activity of three colored onions (Allium cepa L.). Front. Life Sci. 2013, 7, 224-228. [CrossRef]

16. Li, Q.; Wang, Y.; Mai, Y.; Li, H.; Wang, Z.; Xu, J.; He, X. Health Benefits of the Flavonoids from Onion: Constituents and Their Pronounced Antioxidant and Anti-neuroinflammatory Capacities. J. Agric. Food Chem. 2020, 68, 799-807. [CrossRef]

17. Lee, J.; Mitchell, A.E. Quercetin and isorhamnetin glycosides in onion (Allium cepa L.): Varietal comparison, physical distribution, coproduct evaluation, and long-term storage stability. J. Agric. Food Chem. 2011, 59, 857-863. [CrossRef]

18. Yoo, K.S.; Lee, E.J.; Patil, B.S. Quantification of quercetin glycosides in 6 onion cultivars and comparisons of hydrolysis-HPLC and spectrophotometric methods in measuring total quercetin concentrations. J. Food Sci. 2010, 75, C160-C165. [CrossRef]

19. Bonaccorsi, P.; Caristi, C.; Gargiulli, C.; Leuzzi, U. Flavonol glucoside profile of southern Italian red onion (Allium cepa L.). J. Agric. Food Chem. 2005, 53, 2733-2740. [CrossRef]

20. Khoo, H.E.; Azlan, A.; Tang, S.T.; Lim, S.M. Anthocyanidins and anthocyanins: Colored pigments as food, pharmaceutical ingredients, and the potential health benefits. Food Nutr. Res. 2017, 61, 1361779. [CrossRef]

21. Saha, S.; Singh, J.; Paul, A.; Sarkar, R.; Khan, Z.; Banerjee, K. Anthocyanin profiling using uv-vis spectroscopy and liquid chromatography mass spectrometry. J. AOAC Int. 2020, 103, 23-39. [CrossRef]

22. Winter, A.N.; Ross, E.K.; Khatter, S.; Miller, K.; Linseman, D.A. Chemical basis for the disparate neuroprotective effects of the anthocyanins, callistephin and kuromanin, against nitrosative stress. Free Radic. Biol. Med. 2017, 103, 23-34. [CrossRef] [PubMed]

23. Venancio, V.P.; Cipriano, P.A.; Kim, H.; Antunes, L.M.; Talcott, S.T.; Mertens-Talcott, S.U. Cocoplum (Chrysobalanus icaco L.) anthocyanins exert anti-inflammatory activity in human colon cancer and non-malignant colon cells. Food Funct. 2017, 8, 307-314. [CrossRef] [PubMed]

24. Fernández-Jalao, I.; Sánchez-Moreno, C.; de Ancos, B. Influence of food matrix and high-pressure processing on onion flavonols and antioxidant activity during gastrointestinal digestion. J. Food Eng. 2017, 213, 60-68. [CrossRef]

25. Duangjit, J.; Welsh, K.; Wise, M.L.; Bohanec, B.; Havey, M.J. Genetic analyses of anthocyanin concentrations and intensity of red bulb color among segregating haploid progenies of onion. Mol. Breed. 2014, 34, 75-85. [CrossRef]

26. Bahadoran, Z.; Mirmiran, P.; Azizi, F. Dietary polyphenols as potential nutraceuticals in management of diabetes: A review. J. Diabetes Metab. Disord. 2013, 12, 43. [CrossRef]

27. Martinez-Gonzalez, A.I.; Díaz-Sánchez, Á.; de La Rosa, L.; Bustos-Jaimes, I.; Alvarez-Parrilla, E. Inhibition of $\alpha$-amylase by flavonoids: Structure activity relationship (SAR). Spectrochim. Acta Part A 2019, 206, 437-447. [CrossRef]

28. Gois Ruivo da Silva, M.; Skrt, M.; Komes, D.; Poklar Ulrih, N.; Pogačnik, L. Enhanced Yield of Bioactivities from Onion (Allium cepa L.) Skin and Their Antioxidant and Anti- $\alpha$-Amylase Activities. Int. J. Mol. Sci. 2020, 21, 2909. [CrossRef]

29. Anthon, G.E.; Barrett, D.M. Modified method for the determination of pyruvic acid with dinitrophenylhydrazine in the assessment of onion pungency. J. Sci. Food Agric. 2003, 83, 1210-1213. [CrossRef]

30. Yoo, K.S.; Lee, E.J.; Hamilton, B.K.; Patil, B.S. A comparison of juice extraction methods in the pungency measurement of onion bulbs. J. Sci. Food Agric. 2016, 96, 735-741. [CrossRef]

31. Liguori, L.; Califano, R.; Albanese, D.; Raimo, F.; Crescitelli, A.; Di Matteo, M. Chemical Composition and Antioxidant Properties of Five White Onion (Allium cepa L.) Landraces. J. Food Qual. 2017, 2017, 9. [CrossRef]

32. Takeda, E.; Yamamoto, H.; Yamanaka-Okumura, H.; Taketani, Y. Dietary phosphorus in bone health and quality of life. Nutr. Rev. 2012, 70, 311-321. [CrossRef] [PubMed]

33. Khan, N.; Ahmed, M.J.; Shah, S.Z.A. Comparative analysis of mineral content and proximate composition from chilli pepper (Capsicum annuum L.) germplasm. Pure Appl. Biol. 2019, 8, 1338-1347. [CrossRef]

34. Glasdam, S.-M.; Glasdam, S.; Peters, G.H. The Importance of Magnesium in the Human Body: A Systematic Literature Review. Adv. Clin. Chem. 2016, 73, 169-193.

35. Sardesai, V. Introduction to Clinical Nutrition; CRC Press: Boca Raton, FL, USA, 2011.

36. Maret, W.; Sandstead, H.H. Zinc requirements and the risks and benefits of zinc supplementation. J. Trace Elem. Med. Biol. 2006, 20, 3-18. [CrossRef] [PubMed] 
37. Nielsen, F.H.; Meacham, S.L. Growing evidence for human health benefits of boron. J. Evid. Based Complement. Altern. Med. 2011, 16, 169-180. [CrossRef]

38. Mithen, R. Sulphur-Containing Compounds. In Plant Secondary Metabolites: Occurrence, Structure and Role in the Human Diet; Blackwell Publishing Ltd.: Hoboken, NJ, USA, 2006; pp. 25-46.

39. Schaich, K.M.; Tian, X.; Xie, J. Hurdles and pitfalls in measuring antioxidant efficacy: A critical evaluation of ABTS, DPPH, and ORAC assays. J. Funct. Foods 2015, 14, 111-125. [CrossRef]

40. Jayaprakasha, G.K.; Girennavar, B.; Patil, B.S. Antioxidant capacity of pummelo and navel oranges: Extraction efficiency of solvents in sequence. Lwt-Food Sci. Technol. 2008, 41, 376-384. [CrossRef]

41. Sagar, N.A.; Pareek, S.; Gonzalez-Aguilar, G.A. Quantification of flavonoids, total phenols and antioxidant properties of onion skin: A comparative study of fifteen Indian cultivars. J. Food Sci. Technol. 2020, 57, 2423-2432. [CrossRef]

42. Wu, H.; Xu, B. Inhibitory Effects of Onion Against $\alpha$-Glucosidase Activity and its Correlation with Phenolic Antioxidants. Int. J. Food Prop. 2014, 17, 599-609. [CrossRef]

43. Lu, X.; Wang, J.; Al-Qadiri, H.M.; Ross, C.F.; Powers, J.R.; Tang, J.; Rasco, B.A. Determination of total phenolic content and antioxidant capacity of onion (Allium cepa) and shallot (Allium oschaninii) using infrared spectroscopy. Food Chem. 2011, 129, 637-644. [CrossRef]

44. Suleria, H.A.R.; Butt, M.S.; Anjum, F.M.; Saeed, F.; Khalid, N. Onion: Nature Protection Against Physiological Threats. Crit. Rev. Food Sci. Nutr. 2015, 55, 50-66. [CrossRef] [PubMed]

45. Prakash, D.; Singh, B.N.; Upadhyay, G. Antioxidant and free radical scavenging activities of phenols from onion (Allium cepa). Food Chem. 2007, 102, 1389-1393. [CrossRef]

46. Yang, J.; Meyers, K.J.; van der Heide, J.; Liu, R.H. Varietal Differences in Phenolic Content and Antioxidant and Antiproliferative Activities of Onions. J. Agric. Food Chem. 2004, 52, 6787-6793. [CrossRef]

47. Lee, S.U.; Lee, J.H.; Choi, S.H.; Lee, J.S.; Ohnisi-Kameyama, M.; Kozukue, N.; Levin, C.E.; Friedman, M. Flavonoid content in fresh, home-processed, and light-exposed onions and in dehydrated commercial onion products. J. Agric. Food Chem. 2008, 56, 8541-8548. [CrossRef] [PubMed]

48. Serban, M.C.; Sahebkar, A.; Zanchetti, A.; Mikhailidis, D.P.; Howard, G.; Antal, D.; Andrica, F.; Ahmed, A.; Aronow, W.S.; Muntner, P.; et al. Effects of Quercetin on Blood Pressure: A Systematic Review and Meta-Analysis of Randomized Controlled Trials. J. Am. Heart Assoc. 2016, 5, e002713. [CrossRef]

49. Kozlowska, A.; Szostak-Wegierek, D. Flavonoids-food sources and health benefits. Rocz. Panstw. Zakl. Hig. 2014, 65, 79-85.

50. Böttcher, C.; Krähmer, A.; Stürtz, M.; Widder, S.; Schulz, H. Effect of cultivar and cultivation year on the metabolite profile of onion bulbs (Allium cepa L.). J. Agric. Food Chem. 2018, 66, 3229-3238. [CrossRef]

51. Zhang, S.-1.; Peng, D.; Xu, Y.-C.; Lü, S.-W.; Wang, J.-J. Quantification and analysis of anthocyanin and flavonoids compositions, and antioxidant activities in onions with three different colors. J. Integr. Agric. 2016, 15, 2175-2181. [CrossRef]

52. Fossen, T.; Andersen, Ø.M. Anthocyanins from red onion, Allium cepa, with novel aglycone. Phytochemistry 2003, 62, 1217-1220. [CrossRef]

53. Pérez-Gregorio, R.M.; García-Falcón, M.S.; Simal-Gándara, J.; Rodrigues, A.S.; Almeida, D.P.F. Identification and quantification of flavonoids in traditional cultivars of red and white onions at harvest. J. Food Compos. Anal. 2010, 23, 592-598. [CrossRef]

54. Ferreres, F.; Gil, M.I.; Tomás-Barberán, F.A. Anthocyanins and flavonoids from shredded red onion and changes during storage in perforated films. Food Res. Int. 1996, 29, 389-395. [CrossRef]

55. Gennaro, L.; Leonardi, C.; Esposito, F.; Salucci, M.; Maiani, G.; Quaglia, G.; Fogliano, V. Flavonoid and Carbohydrate Contents in Tropea Red Onions: Effects of Homelike Peeling and Storage. J. Agric. Food Chem. 2002, 50, 1904-1910. [CrossRef] [PubMed]

56. Smeriglio, A.; Barreca, D.; Bellocco, E.; Trombetta, D. Chemistry, Pharmacology and Health Benefits of Anthocyanins. Phytother. Res. 2016, 30, 1265-1286. [CrossRef] [PubMed]

57. Amić, D.; Davidović-Amić, D.; Bešlo, D.; Trinajstić, N. Structure-radical scavenging activity relationships of flavonoids. Croat. Chem. Acta 2003, 76, 55-61.

58. Murota, K.; Mitsukuni, Y.; Ichikawa, M.; Tsushida, T.; Miyamoto, S.; Terao, J. Quercetin-4'-glucoside Is More Potent than Quercetin-3-glucoside in Protection of Rat Intestinal Mucosa Homogenates against Iron Ion-Induced Lipid Peroxidation. J. Agric. Food Chem. 2004, 52, 1907-1912. [CrossRef] 
59. Olivas-Aguirre, F.J.; Rodrigo-García, J.; Martínez-Ruiz, N.D.R.; Cárdenas-Robles, A.I.; Mendoza-Díaz, S.O.; Álvarez-Parrilla, E.; González-Aguilar, G.A.; de la Rosa, L.A.; Ramos-Jiménez, A.; Wall-Medrano, A. Cyanidin-3-O-glucoside: Physical-Chemistry, Foodomics and Health Effects. Molecules 2016, 21, 1264. [CrossRef]

60. Li, W.; Chen, S.; Zhou, G.; Li, H.; Zhong, L.; Liu, S. Potential role of cyanidin 3-glucoside (C3G) in diabetic cardiomyopathy in diabetic rats: An in vivo approach. Saudi J. Biol. Sci. 2018, 25, 500-506. [CrossRef]

61. Akkarachiyasit, S.; Charoenlertkul, P.; Yibchok-Anun, S.; Adisakwattana, S. Inhibitory activities of cyanidin and its glycosides and synergistic effect with acarbose against intestinal $\alpha$-glucosidase and pancreatic

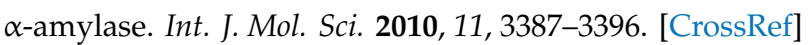

62. Metrani, R.; Jayaprakasha, G.K.; Patil, B.S. Optimized method for the quantification of pyruvic acid in onions by microplate reader and confirmation by high resolution mass spectra. Food Chem. 2018, 242, 451-458. [CrossRef]

63. Acharya, P.; Jayaprakasha, G.K.; Crosby, K.M.; Jifon, J.L.; Patil, B.S. Green-Synthesized Nanoparticles Enhanced Seedling Growth, Yield, and Quality of Onion (Allium cepa L.). Acs Sustain. Chem. Eng. 2019, 7, 14580-14590. [CrossRef]

64. Chaudhary, P.; Jayaprakasha, G.; Porat, R.; Patil, B.S. Degreening and postharvest storage influences 'Star Ruby'grapefruit (Citrus paradisi Macf.) bioactive compounds. Food Chem. 2012, 135, 1667-1675. [CrossRef] [PubMed]

65. Wang, J.; Jayaprakasha, G.K.; Patil, B.S. Chemometric characterization of 30 commercial thermal and cold processed juices using UPLC-QTOF-HR-MS fingerprints. Lwt-Food Sci. Technol. 2019, 114, 108322. [CrossRef]

66. Barkat, N.; Singh, J.; Jayaprakasha, G.K.; Patil, B.S. Effect of harvest time on the levels of phytochemicals, free radical-scavenging activity, $\alpha$-amylase inhibition and bile acid-binding capacity of spinach (Spinacia oleracea). J. Sci. Food Agric. 2018, 98, 3468-3477. [CrossRef] [PubMed]

67. Singh, J.; Jayaprakasha, G.K.; Patil, B.S. Rapid ultra-high-performance liquid chromatography/quadrupole time-of-flight tandem mass spectrometry and selected reaction monitoring strategy for the identification and quantification of minor spinacetin derivatives in spinach. Rapid Commun. Mass Spectrom. 2017, 31, 1803-1812. [CrossRef]

68. Gomez, M.K.; Singh, J.; Acharya, P.; Jayaprakasha, G.; Patil, B.S. Identification and Quantification of Phytochemicals, Antioxidant Activity, and Bile Acid-Binding Capacity of Garnet Stem Dandelion (Taraxacum officinale). J. Food Sci. 2018, 83, 1569-1578. [CrossRef]

69. Singh, J.; Jayaprakasha, G.; Patil, B.S. An optimized solvent extraction and characterization of unidentified flavonoid glucuronide derivatives from spinach by UHPLC-HR-QTOF-MS. Talanta 2018, 188, 763-771. [CrossRef]

(C) 2020 by the authors. Licensee MDPI, Basel, Switzerland. This article is an open access article distributed under the terms and conditions of the Creative Commons Attribution (CC BY) license (http://creativecommons.org/licenses/by/4.0/). 